\title{
Hastane Çalışanlarına Göre Yöneticilerin Çatışma Çözme Stratejileri
}

\author{
Altuğ ÇAĞATAY ${ }^{1}$ ve Ümit ARSLAN ${ }^{2}$
}

\section{$\ddot{\mathrm{Oz}}$}

Bu çalışmada, Elazığ şehir hastanesinde görev yapan sağlık çalışanlarının, bağlı oldukları yöneticilerin kullandıkları çatışma çözme stratejileri hakkında düşüncelerinin belirlenmesi amaçlanmıştır. Veri toplama aracı olarak anket yöntemi kullanılmıştır. Araştırmada Rahim, M. Afzalur tarafından geliştirilmiş ROCI-II olarak isimlendirilen ve 28 maddeden oluşan çatışma yönetim stratejileri ölçeği kullanılmış olup, ölçme aracının güvenirliği 0.87 olarak bulunmuştur. Araştırma hastanedeki 158 kişiye uygulanmış, 134 anket değerlendirmeye alınmıştır. Verilerin normal dağılıma uyması sebebiyle t testi, tek yönlü varyans analizi yapılmıştır. Hastane çalışanlarının demografik özellikleri ile bağlı oldukları yöneticilerine ilişkin çatışma çözme strateji algıları arasındaki ilişki araştırılmıştır. Hastane çalışanlarının cinsiyeti ve unvanı ile yöneticilerin çatışma çözme stratejileri alt boyutları algıları arasındaki ilişki anlamlı bulunmuştur $(\mathrm{p}<0,05)$. Buna göre hastane çalışanlarının yöneticileri hakkındaki çatışma çözme stratejilerine yönelik alg1s1 $\bar{x}=3.03$ değeri ile orta düzeydedir. Kadın çalışanların yöneticileri hakkındaki çatışma yönetimi algısı ( $\bar{x}=3.11)$ olup, erkek çalışanların algısından daha yüksektir $(\bar{x}=2,95)$. Unvana göre sekreterler ve hemşireler ile diğer meslek grupları arasındaki fark anlamlıdır. Hastane çalışanlarına göre yöneticilerinin kullandıkları çatışma çözme stratejileri sırası ile; hükmetme $(\bar{x}=3.18)$, kaçınma $(\bar{x}=3.09)$, bütünleştirme $(\bar{x}=3.03)$, uzlaşma $(\bar{x}=2.98)$ ve uyma $(\bar{x}=2,90)$ çatışma çözme stratejileridir. Hastane çalışanlarına göre kadın yöneticiler en çok bütünleştirme $(\bar{x}=3.11)$, erkek yöneticiler $(\bar{x}=3.19)$ ise hükmetme stratejisini kullanmaktadırlar. Araştırmaya katılanların yaş ve hizmet yılı arttıkça yöneticileri hakkındaki çatışma çözme stratejisi algı ortalamaları da artış göstermiştir.

Anabtar Kelimeler: Çatışma yönetimi stratejisi, hastane çalışanı, hastane yöneticileri, sağlık yönetimi

\section{Conflict Resolution Strategies of Managers According to Hospital Staff}

\section{Abstract}

This study aims to determine the opinions of the health staff working in Elazig City Hospital about the conflict resolution strategies used by their managers. Survey method was used as the data collection tool. This research used the conflict management strategies scale named ROCI II consisting of 28 items developed by Rahim, M. Afzalur. The reliability of the measurement tool was 0.87 . The survey was applied to 158 people in the hospital and 134 questionnaires were included in the evaluation. Since the data fit the normal distribution, t-test and one-way analysis of variance were performed. This study investigated the relationship between the demographic characteristics of the hospital staff and their perception of conflict resolution strategies of their managers. There is a significant $(p<0.05)$ relationship between gender and title of hospital staff and their perceptions regarding the managers' conflict resolution strategies sub-dimensions. Accordingly, the perception of the female employees about conflict management of their managers $(\bar{x}=3.11)$ is higher than that of male personnel $(\bar{x}=2.95)$. According to the hospital staff, female managers use the strategy of integration $(\bar{x}=3.11)$, and male managers use the strategy of domination $(\bar{x}$ $=3.19)$. There is a significant difference between secretaries, nurses, and other professional groups. The perception of hospital staff about their managers' conflict resolution strategies is at a medium level with $\bar{x}=3.03$. According to the hospital staff, the conflict resolution strategies used by their managers are as follows, respectively: domination ( $\overline{\mathrm{x}}$ $=3.18)$, avoidance $(\bar{x}=3.09)$, integration $(\bar{x}=3.03)$, compromise $(\bar{x}=2.98)$ and compliance $(\bar{x}=2.90)$. As the age and service year of the participants increase, the perceptions about the conflict resolution strategy of their managers increase, too.

Key Words: Conflict management strategy, hospital Staff, hospital managers, Healthcare management

\section{Atıf İçin / Please Cite As:}

Çağatay, A. ve Arslan, Ü. (2020). Hastane çalışanlarına göre yöneticilerin çatışma çözme stratejileri. Manas Sosyal Araştırmalar Dergisi, 9(4), 2300-2310.

Geliş Tarihi / Received Date: 25.05.2020

Kabul Tarihi / Accepted Date: 13.08.2020

\footnotetext{
${ }^{1}$ Dr. Öğr. Üyesi - Tokat Gaziosmanpaşa Üniversitesi, Almus Meslek Yüksekokulu, Büro Hizmetleri ve Sekreterlik Bölümü, altug.cagatay@gop.edu.tr ORCID: 0000-0001-7067-5570

2Dr. - T.C. Sağllk Bakanllğ1, umitars@hotmail.com, ORCID: 0000-0002-9781-3723
} 


\section{Giriş}

Çatışma, insanları ortak bir amaca ulaşmak için bir araya getiren örgütlerde sıklıkla karşılaşılan bir durumdur. Günümüzde çatışma örgütler açısından her zaman zarar veren bir durum olarak alg1lanmamakta, çatışmaların örgütte gelişme, verimlilik ve örgütsel değişim gibi birçok konuda örgüte olumlu katkılar yapan bir olgu olduğu genel kabul görmektedir. Bu anlamda örgütlerde çatışma, işletmelerde karar alma, yenilik yapma, problem çözme, çalışanların fikirlerine önem verme ve farklı seslere cesaret verme gibi birçok unsuru destekleyen bir araçtır. Burada önemli olan çatışmayı iyi yönetebilmek, çatışma nedenlerini doğru bir şekilde saptamak ve çatışmanın olumsuz yanlarını ortadan kaldırarak, herkesin uzlaşabileceği en uygun çözümleri bulabilmektir (Kilınç vd., 2018).

Çatışmaların yukarıda bahsedilen olumlu etkilerinden dolayı, belli bir miktar çatışma örgüt performansı açısından gereklidir. Bu nedenle çatışma yönetimi, kabul edilebilir düzeyde çatışmanın örgüt içinde sağlanmasını da içermektedir. Aksi halde çatışmanın yer bulmadığı bir örgütte yenilik ve değişim için gerekli olan itici güç oluşmayacaktır. Bu noktada örgütteki çatısmalar kontrol altına alınarak olumsuz sonuçların ortaya çıkması önlenmeli, yöneticiler olumsuz etkiler ortaya çıkarabilecek olan çatışmalara karşı önlem almalıdır. Çatışma yönetimi açısından bir diğer hususta zararlı etkileri olan çatışmaların yöneticiler tarafindan çözülmesi olup, yöneticiler bu amaçla pasiften aktife doğru birçok teknik kullanmalıdırlar (Kösehan, 2005).

Çatışmaların gerekliliği noktasında dikkate alınması gereken bir başka görüş de Rahim M. Afzalur’a aittir. Rahim M. Afzalur çatışmayı şöyle ele almaktadır: Çatışma kaynakları aynı olsa da, çatışma yönetimi konusunda geçmişten günümüze ciddi bir dönüşüm yaşanmıştır. Örgütsel çatışma ile ilgili olarak geleneksel, davranışçı ve etkileşimci olmak üzere üç temel görüş bulunmaktadır. Geleneksel görüşe göre çatısma, arzu edilmeyen bir durumdur. Çatışma, örgüte ve örgütsel etkililiğe zarar verdiğinden, en aza indirilmesi hatta ortadan kaldırılması gerekmektedir. İkinci görüş olan davranışçı (insan ilişkileri) görüşe göre, bütün grup ve örgütlerdeki çatışmalar doğaldır. Bu görüşü savunanlar, çatışmanın kaçınılmaz oluşu nedeniyle çatışmanın varlığını kabul etmekte, hatta örgütsel etkililiğin artırılması için çatışmanın geliştirilmesini savunmaktadırlar. Üçüncü görüş olan etkileşimci görüşte ise, örgüt içi çatışmanın örgütün sağlığı için son derece önemli olduğu vurgulanmaktadır. Bu görüşü savunanlara göre, çatışmanın mutlak gerekliliği söz konusudur. Bu nedenle karşıt görüşler teşvik edilmekte, değişim ve yenilik esas olmaktadır (Rahim, 2011, s. 8-11; Tozkoparan, 2013, s. 191).

Hastanelerde; iletişim yetersizliği, yetki ve sorumluluk dengesizliği, görev tanımlarının yetersiz yapılması, kararlara katılım eksikliği, yükselme imkânlarının yetersizliği, çalışmaların ilgililerce yeterince takdir edilmemesi, iş doyumsuzluğu, hizmet içi eğitim yetersizliği, etkin ekip çalışmasının uygulanamayışı, vb. sebepler örgütsel çatışma sebepleri olarak görülmektedir (Aslan, 2004). Öte yandan hastanelerde çatışmalara neden olan kişilik, rol, statü ve amaç farklılıkları gibi diğer faktörlerin de, örgütün faydasına olabilmesi ya da örgütün etkinliğine ve gelişmesine katkıda bulunabilmesi, yöneticilerin kurum içindeki çatışmaları etkin ve olumlu bir biçimde yönetmesine bağlıdır. Yöneticiler kurum içindeki çatısmayı yönetme ve çözümlemede en önemli role sahip olup; karşılaştı̆̆1 sorunlar1 çözmek, örgüt içi gruplar arasında görülen olumsuzluklanı yok edebilme becerisine sahip kararlar vermek ve alternatiflerden en uygun olanını seçmek durumundadırlar. Bu nedenle yöneticiler kişisel becerilerini kullanarak çatışmaları çözmek zorundadırlar (Uslu, 2015).

Hastanelerde pek çok yönetici kurumlarında bir çatışma yaşandığında kaçınma, taviz verme, güç kullanma, yumuşatma, problem çözme stillerini kullanmakta ve çatışma yönetimini yeterli düzeyde uyguladıklarını düşünmektedir. Oysa çalışanlar aynı çatışmada yöneticilerinin çatışma yönetimi konusunda yeterli davranışları göstermedikleri algısına sahiptirler (Kıdak vd., 2011)

\section{Yöntem}

Araştırmada, Rahim (2002) tarafindan geliştirilen örgütsel çatışma ölçeği kullanılmıştır. Günümüzde en yaygin olarak kullanılan modellerden birisi, Rahim Organizational Conflict Inventory-II veya ROCI-II olarak bilinen bir ölçek geliştiren Rahim'in (1983) modelidir. Rahim, çatışmalar ile çatş̧ma yönetim tarzlarını, kendi çıkarını düşünme ve başkalarının çıkarını düşünme boyutlarının kombinasyonunu oluşturarak sınıflandırmıştır. $\mathrm{Bu}$ modelde kişinin kendisine yönelik ilgisi ve başkalarına yönelik ilgisi olmak üzere iki boyut vardır. $\mathrm{Bu}$ boyutlara göre kullanılan çatşma çözme stratejileri beş grupta toplanmış olup bunlar; bütünleştirme/problem çözme, uyma/ödün verme, uzlaşma, hükmetme/baskın olma ve kaçınma olarak ifade edilmektedir. 


\section{Evren - Örneklem}

Araştırma Elazığ Şehir Hastanesi'nde yapılmıştır. Veri toplama aracı olarak anket kullanılmış olup, ölçme aracının güvenirliği 0.87 olarak bulunmuştur. Çalısma 12 Şubat 2019- 10 Mart 2019 tarihleri arasında yapılmış, çalışmada 158 çalışana anket uygulanmış ancak 134 anket değerlendirmeye alınmıştır. Veriler normal dağılıma uyduğundan t testi, tek yönlü varyans analizi yapılmıştır. Araştırmanın amacı, hastane çalışanlarının bağlı oldukları yöneticilerin çatışma çözme stratejilerini nasıl kullandıklarının belirlenmesi amacı ile çalışan personelin algılarının analiz edilmesidir. Araştırma için Elazı̆̆ Fethi Sekin Şehir Hastanesi Başhekimliğ̣i’nden 12.02.2019 tarih ve 702.99-E.1771 saylı yazı ile izin alınmıştır.

\section{Veri Toplama Araçları}

Araştırma Elazığ Şehir Hastanesi'nde yapılmıştır. Veri toplama aracı olarak anket kullanılmış olup, ölçme aracının güvenirliği 0.87 olarak bulunmuştur. Çalışma 12 Şubat 2019- 10 Mart 2019 tarihleri arasında yapılmış, çalışmada 158 çalışana anket uygulanmış ancak 134 anket değerlendirmeye alınmıştır. Veriler normal dağılıma uyduğundan $\mathrm{t}$ testi, tek yönlü varyans analizi yapılmıştır. Çalışmada, Rahim M. Afzalur (1992) tarafindan geliştirilmiş ROCI II olarak isimlendirilen 28 maddeden oluşan "Çatışma Yönetim Stratejileri Ölçeği” kullanılmıştır. Beşli likert tipi ölçekte önermeler; her zaman (5), çoğunlukla (4), ara sıra (3), az (2), çok az (1) olarak derecelendirilmiştir. Ölçekte beş alt boyut vardır ve her bir alt boyut için ortalama puan hesaplanmaktadır. Boyutlar arasındaki en yüksek puan, anlaşmazlık durumunda en çok kullanılan tarzı göstermektedir. Ölçek puanı değerlendirmede çatışma çözme stratejileri ortalama puanı; 1.00-1.79 puan aralığında çok zayıf; $1.80-2.59$ puan aralı̆̆ında zayıf; 2.60-3.39 puan aralı̆ı̆nda orta; 3.404.19 puan aralığında güçlü; 4.20-5.00 puan aralığında ise çok güçlü olarak yorumlanmıştır.

\section{Verilerin Analizi}

Araştırmada, hastane çalışanlarına göre hastane yöneticilerinin çatışma çözme stratejilerini nasıl kullandıklarına yönelik bulgular elde edilmiştir Araştırmadan elde edilen veriler, SPSS programında değerlendirilmiştir. Araştırma, anketi cevaplayan hastane çalş̧anlarınca Örgütsel Çatışma Envanteri Ölçeğine verilen yanıtlar ile sınırlı olup elde edilen veriler ile genelleme yapılması mümkün değildir. Araştırmanın hipotezleri olarak;

H1. Hastane çalışanlarının demografik özellikleri ile yöneticilerinin çatışma çözme stratejilerine ilişkin algiları arasinda fark vardır.

H2. Hastane çalşsanları ile yöneticilerinin demografik özellikleri ile çatışma çözme stratejileri algıları arasında fark vardır.

\section{Bulgular}

\section{Araştırmaya Katılan Hastane Çalışanlarının Demografik Verileri}

Tablo 1. Hastane Calişanlarmm Demografik Özellikleri

\begin{tabular}{lllc}
\hline & Demografik özellikler & n & $\%$ \\
\hline \multirow{2}{*}{ Cinsiyet } & Kadın & 58 & 43,3 \\
& Erkek & 76 & 56,7 \\
\hline \multirow{3}{*}{ Unvanı } & Doktor & 22 & 16,4 \\
& Hemşire & 33 & 24,6 \\
& Diğer sağlik personeli & 29 & 21,6 \\
& Sekreter & 32 & 23,9 \\
& Diğer personel & 18 & 13,4 \\
\hline \multirow{3}{*}{ Yaş } & $18-24$ & 10 & 7,5 \\
& $25-34$ & 51 & 38,1 \\
& $35-44$ & 43 & 32,1 \\
Toplam Hizmet Süresi & 45 ve üstü & 30 & 22,4 \\
\hline & $0-5$ & 15 & 11,2 \\
& $6-10$ & 30 & 22,4 \\
& $11-15$ & 45 & 33,6 \\
\end{tabular}


Araştırmaya katılan 134 hastane çalışanının \% 43.3’ü kadın, \% 56.7’si erkektir. Unvanlarına göre araştırmaya doktor unvanlı 22 kişi ((\% 16.4), hemşire unvanlı 33 kişi (\% 24.6), sekreter unvanlı 32 kişi (\% 23.9) katılırken, diğer sağlık çalışanı olarak 29 kişi (\% 21.6) ve diğer çalışan olarak da 18 kişi (\% 13.4) katılmıştır.

Araştırmaya katılan hastane çalışanlarının yaşları ise 18-24 yaş grubunda 10 kişi (\% 7,5), 25-34 yaş grubunda 51 kişi (\%38.1), 35-44 yaş grubunda 43 kişi (\% 32.1) ve 45 yaş ve üstü 30 kişidir (\%22.4).

Toplam hizmet süresi bakımından 0-5 yıl hizmet süresi olan 15 kişi (\%11.2), 6-10 y1l 30 kişi (\%22.4), 11-15 y1l 45 kişi (\% 33.6) ve 16 y1l üstü 44 kişidir (\%32.8).

\section{Hastane Çalışanlarının Yöneticilerinin Demografik Özellikleri}

Tablo 2. Hastane Çalısanlarnın Yöneticilerinin Demografik Öz̨ellikleri

\begin{tabular}{|c|c|c|c|}
\hline \multicolumn{2}{|c|}{ Demografik özellikler } & \multirow{2}{*}{$\frac{n}{43}$} & \multirow{2}{*}{$\frac{\%}{32.1}$} \\
\hline Cinsiveti & Kadın & & \\
\hline Cinstyet & Erkek & 91 & 67.9 \\
\hline \multirow{3}{*}{ Medeni Durumu } & Evli & 113 & 84,3 \\
\hline & Bekâr & 13 & 9,7 \\
\hline & Boşanmış & 8 & 6,0 \\
\hline \multirow{3}{*}{ Yaş1 } & $25-34$ & 15 & 11,2 \\
\hline & $35-44$ & 49 & 36,6 \\
\hline & 45 yaş ve üstü & 70 & 52,2 \\
\hline \multirow{5}{*}{ Yöneticilik hizmet yılı } & $1-3 \mathrm{y} 1 \mathrm{l}$ & 27 & 20,1 \\
\hline & $4-7 \mathrm{yll}$ & 10 & 7,5 \\
\hline & $8-11$ y1l & 16 & 11,9 \\
\hline & $12-15 \mathrm{y} 1 \mathrm{l}$ & 26 & 19,4 \\
\hline & 16 y1l ve üstü & 55 & 41,0 \\
\hline \multirow{5}{*}{ Eğitim Durumu } & Lise & 6 & 4,5 \\
\hline & Lisans & 56 & 41,8 \\
\hline & Yüksek lisans & 31 & 23,1 \\
\hline & Tipta uzmanlık/doktora & 41 & 30,6 \\
\hline & Toplam & 134 & 100,0 \\
\hline
\end{tabular}

Araştırmaya katılan hastane çalışanlarından alınan yöneticilerinin demografik özelliklerine ilişkin bilgiler tablo 2'de verilmiştir. Buna göre hastane çalışanlarının bağlı olduğu yöneticilerin \% 32.1’i bayan, \% 67.9’u erkektir. Yöneticilerin \% 84.3'ü evli, \% 11.2'si bekârdır. Yöneticilerin yaşlarına bakıldı̆̆ında çoğunluğunun 35 yaş ve üzerinde olduğu görülmektedir. Yöneticilerin \% 20.1’’ 1-3 y1l arası ve \% 41 ’i 16 y1l ve üstü yöneticilik deneyimine sahiptirler. 


\section{Analiz Bulguları}

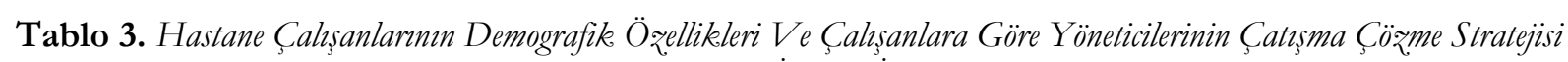
Algilar A rasindaki Illiskije İliskin Bulgular

\begin{tabular}{|c|c|c|c|c|c|c|}
\hline & ğ̆ımsız Değişkenler & & eticil & ma & strateji & \\
\hline Personelin & & $\mathrm{n}$ & Ort. & s.s. & $\mathrm{F}$ & Sig. \\
\hline Cinsiveti & Kadın & 58 & 3,11 & ,37 & 2,180 & 031 \\
\hline 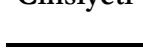 & Erkek & 76 & 2,95 & , 46 & & \\
\hline & Doktor & 22 & 2,96 & ,27 & 1,189 & 322 \\
\hline & Hemşire & 33 & 3,08 & ,39 & & \\
\hline Unvanı & Sekreter & 29 & 3,13 & ,34 & & \\
\hline & Diğer sağlık personeli & 32 & 2,98 &, 58 & & \\
\hline & Diğer personel & 18 & 3,10 & , 48 & & \\
\hline & $18-24$ & 10 & 3,01 & .36 & 1,043 & ,376 \\
\hline Yaș1 & $25-34$ & 51 & 2,97 & .47 & & \\
\hline & $35-44$ & 43 & 3,08 & .54 & & \\
\hline & 45 ve üstü & 30 & 3,17 & 50 & & \\
\hline & $0-5$ & 15 & 2,80 & ,35 & 1,727 & 165 \\
\hline Toplam & $6-10$ & 30 & 3,02 & ,34 & & \\
\hline Süresi & $11-15$ & 45 & 3,06 &, 53 & & \\
\hline & 16 yll ve üstü & 44 & 3,14 & ,37 & & \\
\hline
\end{tabular}

$*$ t testi $* *$ ANOVA testi

Tablo 3'te hastane çalışanlarının cinsiyetine göre çalıştıkları yöneticileri hakkındaki çatışma yönetimi stratejileri algı sonuçları verilmiştir. Buna göre hastane çalışanlarının cinsiyetine göre kadın ve erkek çalısan arasındaki fark istatistiksel olarak anlamlıdır $(\mathrm{p}<0,05)$. Kadın çalışanların yöneticileri hakkındaki çatışma çözme stratejileri anketine verdikleri yanıtların ortalaması $(\bar{x}=3.11)$ değeri ile, erkek çalş̧anlardan daha yüksektir $(\bar{x}=2,95)$. Bu sonuçlara göre kadın çalışanlar yöneticilerinin çatışma yönetim stratejilerini daha çok kullandıklarını göstermektedir. Hastane çalısanlarının demografik özellikleri ve çalısanlara göre yöneticilerinin çatışma çözme stratejileri alt boyutları algıları ile yapılan analizde (Tablo.5) bu farkın "hükmetme alt boyutuna" verilen yanıtlarda olduğu görülmüştür. Kadın çalışanlar $(\bar{x}=3.33)$, yöneticilerinin hükmetme çatışma çözme stratejisini kullandıklarını, erkek çalışanlardan $(\overline{\mathrm{x}}=2.99)$ daha yüksek ortalama ile yanıtlamışlardır. Bu fark istatistiksel olarak anlamlıdır $(\mathrm{p}<0,05)$. Hastane çalışanlarının verdikleri yanıtlara göre kadın çalışanlar yöneticilerinin daha çok hükmetme $(\bar{x}=3.34)$, kaçınma $(\bar{x}=3.15)$, bütünleştirme $(\bar{x}=3.13)$ stratejilerini kullandıklarını erkek çalışanlardan daha yüksek ortalama ile belirtmişlerdir. Erkek çalışanlar ise yöneticilerin uyma stratejisini daha çok kullandıklarını, kadın çalışanlara göre daha yüksek ortalama ile yanıtlamışlardır.

Tablo 3'te hastane çalışanlarının yaşları ve toplam hizmet yılları ile çalışanların, yöneticilerinin kullandığı çatışma çözme stratejilerine yönelik algısına ilişkin tek yönlü varyans analizi sonuçları yer almaktadır. Buna göre çalışanların yaş ve toplam hizmet yılı ile yöneticilerinin çatışma stratejilerini kullanma durumu arasındaki ilişki istatistiksel olarak anlamlı bulunmamıştır ( $\mathrm{p}>0,05)$. Ancak yaş ve hizmet yllı arttıkça, çalışanların yöneticileri hakkındaki çatışma çözme stratejisi algı ortalamaları da artmaktadır. Diğer bir ifade ile yaşı, dolayısı ile hizmet yılı büyük olan çalışanlar, yöneticilerinin çatışma çözme stratejilerini daha çok kullandığını düşünmektedir denilebilmektedir. 
Tablo 4. Hastane Calışanlarmın Bağh Olduklar Yöneticilerin Demografik Özellikeleri ve Hastane Calışanlarına Göre

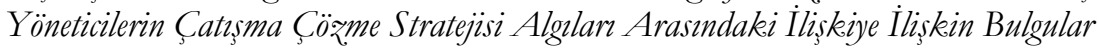

\begin{tabular}{|c|c|c|c|c|c|c|}
\hline \multicolumn{2}{|c|}{ Bağımsız Değişkenler } & \multicolumn{5}{|c|}{ Yöneticilerin Çatışma Çözme Stratejileri } \\
\hline Yöneticinin & & $\mathrm{n}$ & Ort. & s.s. & $\mathrm{F}$ & Sig. \\
\hline \multirow{2}{*}{ Cinsiyeti } & Kadin & 43 & 3,00 & 61 &,- 792 & 431 \\
\hline & Erkek & 91 & 3,12 & 62 & & \\
\hline \multirow{3}{*}{ Medeni durumu } & Evli & 113 & 3,04 & ,45 & 1,473 & 233 \\
\hline & Bekâr & 13 & 2,87 & ,31 & & \\
\hline & Boşanmış & 8 & 2,86 & ,29 & & \\
\hline \multirow{3}{*}{ Yaş1 } & $25-34$ & 15 & 2,83 & ,51 & 1,216 &, 302 \\
\hline & $35-44$ & 49 & 3,09 &, 56 & & \\
\hline & 45 yaş ve üstü & 70 & 3,15 & ,68 & & \\
\hline \multirow{5}{*}{$\begin{array}{l}\text { Yöneticilik hizmet } \\
\text { yilı }\end{array}$} & $1-3$ y1l & 27 & 3,04 & ,41 & ,604 & 661 \\
\hline & 4-7 yil & 10 & 3,10 & 27 & & \\
\hline & 8-11 y1l & 16 & 2,87 &, 39 & & \\
\hline & $12-15 \mathrm{yll}$ & 26 & 3,05 & ,48 & & \\
\hline & 16 y1l ve üstü & 55 & 3,09 & ,45 & & \\
\hline
\end{tabular}

* t testi **ANOVA testi

Tablo 4'te hastane çalışanlarının bağlı oldukları yöneticilerin demografik özellikleri ve hastane çalışanlarına göre yöneticilerinin çatışma çözme stratejisi algıları arasındaki ilişkiye ilişkin bulgular verilmiştir. Buna göre çalışanların yöneticilerinin demografik özellikleri ile çatışma çözme stratejileri genel ortalamaları arasında istatistiksel olarak anlamlı bir fark bulunmamıştır ( $>>0,05)$. Bununla birlikte çalışanlara göre erkek yöneticiler $(\bar{x}=3.12)$ kadın yöneticilere $(\bar{x}=3.00)$ göre çatışma çözme stratejilerini daha fazla kullanmaktadir.

Tablo 5. Hastane Calışanlarmm Demografike Özellikleri ve Calısanlara Göre Yöneticilerin Çatışma Cözme Stratejisi Alt Boyutları Algzlar Arasindaki İlişkiye İlişkin Bulgular

\begin{tabular}{|c|c|c|c|c|c|c|c|c|c|c|}
\hline \multirow{2}{*}{$\begin{array}{c}\text { Personelin } \\
\text { demografik } \\
\text { özellikleri }\end{array}$} & \multicolumn{2}{|c|}{ Bütünleştirme } & \multicolumn{2}{|c|}{ Uyma } & \multicolumn{2}{|c|}{ Hükmetme } & \multicolumn{2}{|c|}{ Kaçınma } & \multicolumn{2}{|c|}{ Uzlaşma } \\
\hline & $t / F$ & $\bar{p}$ & $t / F$ & $\mathrm{p}$ & $t / F$ & $\mathrm{p}$ & $t / F$ & $\bar{p}$ & $t / F$ & $\mathrm{p}$ \\
\hline Cinsiyeti & 1,647 & ,102 &,- 510 & ,611 & 2,671 & ,009 & 1,640 & 103 & 1,662 & ,099 \\
\hline Unvanı & 1,293 & ,276 & 1,070 & ,374 & 3,970 & ,005 & 2,297 &, 063 & 1,295 & ,275 \\
\hline Yaş1 & 2,037 &, 112 & 1,750 & ,160 & 290 &, 833 & ,497 & ,685 & ,408 &, 747 \\
\hline Hizmet süresi & 2,570 & 057 & 1,937 & ,127 & 106 & ,957 & ,616 & ,606 & ,493 & ,687 \\
\hline
\end{tabular}

$*$ t testi $* *$ ANOVA testi

Tablo 5'te hastane çalışanlarının çatışma çözme ölçeğindeki sorulara verdikleri yanıtlar 1şı̆̆ında, çalışanlara göre yöneticilerin kullandıkları çatışma çözme stratejileri ile ilgili bulgular verilmiştir. Hastane çalışanlarının demografik özelliklerinden yaş ve hizmet yılı ile çalışanlara göre yöneticilerin çatışma çözme stratejisi alt boyutları algıları arasında anlamlı bir ilişki yoktur ( $>>0.05)$. Diğer yandan hastane çalışanlarının cinsiyeti ve unvanı ile hükmetme stratejisi arasındaki ilişki istatistiksel olarak anlamlıdır $(\mathrm{p}<0,05)$. Buna göre kadın çalışanlar $(\bar{x}=3.33)$ erkek çalışanlara $(\bar{x}=2.99)$ göre yöneticilerin hükmetme stratejisini daha çok kullandıklarını belirtmişlerdir.

Unvanlara göre bakıldığında sekreterler $(\bar{x}=3.47)$ ve hemşireler $(\bar{x}=3.29)$ ile diğer unvanlar arasındaki, yöneticilerin kullandığ1 hükmetme stratejisi algısı arasındaki fark anlamlıdır $(\mathrm{p}<0,05)$. Sekreter ve hemşireler yöneticilerin hükmetme stratejisini daha fazla kullandıklarını, doktor unvanına sahip personeller ise yöneticilerin bütünleştirme ve uyma stratejisini daha çok kullandığını belirtmişlerdir. 
Tablo 6. Yöneticilerin Demografik Özellikleri Ve Hastane Çalısanlarna Göre Yöneticilerinin Çatısma Çözme Stratejisi Algilar Alt Boyutlarn Arasindaki Iliskije Ilişkin Bulgular

\begin{tabular}{|c|c|c|c|c|c|c|c|c|c|c|}
\hline \multirow{2}{*}{$\begin{array}{c}\text { Yöneticilerin } \\
\text { demografik } \\
\text { özellikleri }\end{array}$} & \multicolumn{2}{|c|}{ Bütünleştirme } & \multicolumn{2}{|c|}{ Uyma } & \multicolumn{2}{|c|}{ Hükmetme } & \multicolumn{2}{|c|}{ Kaçınma } & \multicolumn{2}{|c|}{ Uzlaşma } \\
\hline & $t / F$ & $\mathrm{p}$ & $\mathrm{t} / \mathrm{F}$ & $\mathrm{p}$ & $\mathrm{t} / \mathrm{F}$ & $\bar{p}$ & $\mathrm{t} / \mathrm{F}$ & $\mathrm{p}$ & $\mathrm{t} / \mathrm{F}$ & $\mathrm{p}$ \\
\hline Cinsiyeti* & 1,124 & ,263 & 1,091 & 277 & $-1,026$ &, 307 &,- 942 & ,348 & $-1,843$ & 071 \\
\hline Medeni durumu &, 244 &, 784 &, 772 & ,464 & 2,126 & ,123 & 1,007 &, 368 & 1,070 &, 374 \\
\hline Eğitim durumu & 1,439 & ,234 & 1,800 & ,150 & 4,036 & ,009 & 1,873 & ,137 & 1,076 & ,284 \\
\hline Yaş1 & 2,623 & ,076 & 2,168 & ,118 & 2,625 & ,076 & 1,359 & 260 &, 113 & 894 \\
\hline Hizmet süresi & 1,454 & 220 &, 638 &, 636 & 1,921 & 111 & 1,067 &, 375 & ,976 &, 423 \\
\hline
\end{tabular}

$*$ t testi $* *$ ANOVA testi

Tablo 6'da Hastane yöneticilerinin demografik özellikleri ve hastane çalışanlarına göre yöneticilerin çatışma çözme stratejisi algıları alt boyutları arasındaki ilişkiye yönelik bulgular verilmiştir. Buna göre yöneticilerin cinsiyeti, medeni durumu, yaşı ve hizmet süresi ile kullandıkları çatışma çözme stratejileri alt boyutları arasında anlamlı bir ilişki bulunmamıştır $(p>0,05)$. Diğer yandan bir diğer demografik özellik olan yöneticilerin eğitim durumuna ilişkin gruplar arasındaki fark anlamlı bulunmuştur. Buna göre eğitim durumu lisans olan yöneticiler, çalışanların verdikleri yanıtlara göre hükmetme stratejisini daha çok kullanmaktadırlar. Eğitim durumu tıpta uzmanlık/doktora olanların ise bütünleştirme stratejisini daha çok kullandıkları görülmüştür. Yöneticilerin cinsiyet özellikleri açısından bakıldığında ise, hastane çalışanlarına göre kadın yöneticiler en çok bütünleştirme stratejisini $(\overline{\mathrm{x}}=3.11)$, erkek yöneticiler $(\overline{\mathrm{x}}=3.19)$ ise hükmetme stratejisini kullanmaktadırlar.

Hastane çalışanlarının bağlı oldukları yöneticilerine yönelik düşüncelerini ifade ettikleri Örgütsel Çatışma Envanteri'ne (Çatısma Çözme Yaklaşımları Ölçeği) verdikleri yanıtlarda en yüksek ortalama $(\bar{x}=3.48)$ yöneticim "kendi fikirlerini kabul ettirmek için bask1 yapar." ve yöneticim "bazen rekabet gerektiren bir durumda kazanmak için yönetim yetkisini kullanır" $(\bar{x}=3.38)$ ifadelerine verilmiştir. En düşük ortalamalar ise yöneticim "hepimizin kabul edeceği bir çözüm bulabilmek için sorunu bizimle birlikte incelemeye çalışır" ( $\bar{x}=2.72)$ ve yöneticim "uzlaşma sağlamak için bizlerle pazarlık yapar" $(\bar{x}=2.76)$ ifadelerine verilmiştir. Hastane çalışanlarının yöneticileri hakkındaki çatışma çözme stratejilerine yönelik algısının $\bar{x}=3.03$ orta derecede olduğu görülmüştür. Hastane çalışanlarına göre yöneticilerinin kullandıkları çatışma çözme stratejileri sırası ile; hükmetme $(\bar{x}=3.18)$, kaçınma $(\bar{x}=3.09)$, bütünleştirme $(\bar{x}=3.04)$, uzlaşma $(\overline{\mathrm{x}}=2.98)$ ve uyma $(\overline{\mathrm{x}}=2,90)$ çatışma çözme stratejileridir.

\section{Tartı̧̧ma, Sonuç ve Öneriler}

Çalışmada hastane çalışanlarına göre, bağlı oldukları yöneticilerinin çatışma çözme stratejilerinden hangilerini kullandıklarına yönelik çıkarımlar elde edilmeye çalısılmıştır. Yöneticilerin çatışma stratejilerini kullanmalarına ilişkin algıları bakımından kadın çalışanlar ile erkek çalışanlar arasındaki fark anlamlı bulunmuş, kadın çalışanlar, yöneticilerin çatışma çözme stratejilerini daha yüksek ortalama ile yanıtlamıştır.

Kadın çalışanlara göre yöneticiler çatışma çözme stratejileri alt boyutlarından en fazla hükmetme stratejisini kullanırken, erkek çalışanlar yöneticilerin daha çok uyma stratejisini kullandığını belirtmişlerdir. Bununla birlikte kadın çalışanlar yöneticilerin çatışma çözme stratejilerinden bütünleştirme, kaçınma ve uzlaştırma stratejilerini de kullandıklarını erkek çalışanlara göre daha yüksek ortalama ile belirtmişlerdir. Ancak bu farklılık sadece hükmetme boyutunda anlamlı bulunmuştur. Kıdak vd. (2011) tarafından yapılan çalışmada da yöneticilerin kullandıkları çatışma yönetim stilleri ile ilgili, çalışanların algılamaları ve çalş̧anların cinsiyetleri arasında istatistiksel olarak önemli bir fark bulunmuştur. Söz konusu çalışmada kadın çalışanlar, yöneticilerin kullandıkları bütünleştirme, kaçınma ve uzlaştırma strateji derecelerinin erkek çalş̧anlara göre daha yüksek derecede olduklarını ifade etmişlerdir. Bu çalışmada da benzer sonuç görülmüş ancak bu fark hükmetme boyutunda anlamlı bulunmuştur.

Unvanlara göre bakıldığında sekreter ve hemşire ile diğer unvanlar arasındaki, yöneticilerin kullandığı hükmetme stratejisi algısı arasındaki fark anlamlı bulunmuştur. Sekreter ve hemşire unvanına sahip çalışanların çoğunluğu kadın çalışanlar olup, yöneticilerin hükmetme stratejisini daha fazla kullandıklarını belirtmişlerdir. 
Doktor unvanına sahip çalışanlar ise, yöneticilerinin bütünleştirme ve uyma stratejisini daha çok kullandığını belirtmiştir. Bu durumun yapılan işle ilgili olduğu düşünülmektedir. Bunun yanı sıra hastanelerde yapılan işlerin hizmetlerin özelliğine bağlı olarak ertelenemez ve birbiri ile bağlantılı şekilde sistem yaklaşımı içerisinde yürütülmesi gerekmektedir. Aksi halde bir yerdeki aksaklık tüm sistemi etkilemektedir.

Hastaneler hizmet yoğun organizasyon yapısına sahip kuruluşlar olup, bu hizmetler acil ve ertelenemez durumdadır. Bu nedenle sistemin işleyişini etkileyecek bireysel ve diğer çatışmaların hızla çözülmesi gerekmektedir. Araştırmada çalışanlar, bağlı oldukları yöneticilerin çatışmaların çözümünde en çok hükmetme stratejisini, en az ise uyma stratejisini kullandıklarını belirtmişlerdir. Bunun sebebi olarak, hastanelerin matriks organizasyon yapısında olması, farklı iş bölümü ve uzmanlıkların yer almasıdır. Hizmetlerin ardışı ve birçok birimi birbiri ile ilişkili olması ve hastane hizmet sürecine dahil bu yapı kesintisiz devam etmesi gerekir. Bu işleyiş içerisinde yaşanacak çatışmalarda yöneticilerin çatışmaları hızlı bir şekilde çözmeleri bir zorunluluk halini almaktadır. Yöneticilerce çatışmaların çözümünde öncelikle yönetim yetkisinin kullanıldığı düşünülmektedir. Hastanelerde çatışmaların çözümünde problem çözme yaklaşımının daha etkin kullanılması gerekmektedir.

Aslan (2004) tarafindan yapılan çalı̧şmada da durum cinsiyet faktörü üzerinden incelenmiş, erkek çalışanların çatısma konusunda daha iyimser yaklaşım içerisinde bulundukları ve görev tanımlarının yapılmayışı sebebiyle en fazla mağdur olan kesimin genellikle kadın çalışanlar olan hemşireler olduğu ifade edilmiştir.

Önder ve arkadaşlarınca (2014) yapılan çalışmada, hemşirelerin birinci stres kaynağının iş yükü olduğu belirtilmiştir. Yine ilgili çalısmada, Stordeur vd.'nin (2001) hemşirelere ait stres faktörleri aktarılmıştır. Buna göre hemşirelerin başlıca stres faktörleri; ağır iş yükü, diğer hemşireler ya da doktorlarla çatışma, hedef ve görevlerle ilgili belirsizlik yaşamak, sürekli olarak başhemşirenin yakın gözetiminde olup düzeltici eylemine maruz kalmak olarak sıralanmıştır. Bu ve benzer faktörlerin hemşirelerin araştırmada, yöneticileri hakkındaki çatışma çözme stratejilerine yönelik algilanı üzerinde etkili nitelikte olduğu ve araştırma sonucunu desteklediği düşünülmektedir. Akca ve Erigüç (2006) tarafindan yapılan çalışmada da, hastane çalışanlarının çalışma arkadaşları ile yaşadıkları çatışmaların nedenleri olarak; karşılıklı görev bağımlılı̆̆ı, yetki ve sorumluluk belirsizliği, algılama farklılı̆̆ı, amaç, çıkar ve değer farklıllğı ve ödül sistemi farklıllğı ile hastane çalışanlarının meslek grupları arasında anlamlı bir fark bulunmuştur.

Hastane çalışanlarının bağlı oldukları yöneticilerinin demografik özellikleri ve hastane çalışanlarına göre yöneticilerinin çatışma çözme stratejisi algıları arasında istatistiksel olarak anlamlı bir fark bulunmamıştır. Bununla birlikte çalışanlara göre, erkek yöneticiler kadın yöneticilere göre çatışma çözme stratejilerini daha fazla kullanmaktadır.

Çatışma çözme envanterine verilen en yüksek ortalamalı yanıt, yöneticim "kendi fikirlerini kabul ettirmek için baskı yapar" ifadesine; en düşük ortalamalı yanıt ise yöneticim "uzlaşma sağlamak için bizlerle pazarlık yapar ifadesine verilmiştir. Genel olarak çalşanların, yöneticileri hakkındaki çatışma çözme stratejilerini kullanma görüşleri orta derecededir. Çalışanlar, yöneticilerinin kullandıkları çatışma çözme yöntemlerini en yüksek düzeyde hükmetme, en düşük düzeyde uyma çatşma çözme stratejisi olarak algıladıklarını belirtmişlerdir.

Kıdak ve arkadaşları (2011) tarafından İzmir'de bir eğitim ve araştırma hastanesinde yapılan çalışmada çalışanların, yöneticilerin çatışma yönetim stillerini algılamalanı incelenmiştir. Çalışanlar yöneticilerinin çatışma stillerini en yüksek düzeyde bütünleştirme, en düşük düzeyde kaçınma olarak algıladıklarını belirtmişlerdir. İlgili çalışmada yöneticilerin çatışma yönetimi algılarının, çalışanlarının algılarından daha olumlu olduğu, çatışma ortamına daha fazla açı olan hastanelerde, yöneticilerin temel olarak sahip olması gereken kavram ve becerilerden birinin çatışma yönetimi olduğu ve bu konuda eğitim programlarının yapılması gerektiği belirtilmiştir.

Oktay (2016) tarafindan yapılan araştırmada, çalışanların çatışma yönetim tarzları ile algıladıkları örgütsel destek arasında anlamlı bir ilişsi bulunduğu ifade edilmekte olup çatışma yönetim tarzının, alg1lanan örgütsel desteği yordayan boyutlardan biri olduğu belirtilmiştir.

Koç (2017) tarafindan yapılan İzmir ilinde bir kamu hastanesinde hemşirelerin çatışma yönetiminin incelenmesi konulu yüksek lisans çalışmasında, çatışmaların çözümüne yönelik yapılan ankette katılımcıların \%57'si çalışanlar arasında çıkan çatışmalarda çalışanların yerlerinin değiştirilmesi ile çözümlendiğini bunun dışında çözüme yönelik ciddi bir çalışma ya da müdahale olmadığını savunmaktadırlar. Katılımcıların \%45’i kurumda yaşanan çatışmalara, her iki tarafın isteklerinin de göz önüne alınarak çözüm bulunduğu fikrine katılmadıklarını belirtmişlerdir. Araştırmanın hemşirelerin yaşadığı çatışmaların nedenine yönelik kısmında, katılımcıların \%78’ çatışmaya yetki ve sorumluluk 
belirsizliğinin sebep olduğunu savunurken; \%67’lik bir kısım ise bazı çalışanların diğer çalışanlar üzerinde egemenlik kurmaya çalışmasından kaynaklandığını belirtmiştir.

Uslu (2015) tarafindan hastanelerde çatışma nedenlerinin araştırıldığı yüksek lisans çalışmasında; çatışmanın nedeni olarak, çalışan görüşlerinin alınmaması, aşırı iş yükü ve angarya, görev tanımının olmaması, yöneticilerin baskıcı tavırları, yetersiz iletişim, çalş̧anlara eşit davranılmaması ve doktorların hekimlik dışı alanlarda aşırı müdahale etme durumu belirtilmiştir.

Baltacı (2013) tarafından yapılan yeni liderlik yaklaşımlarının ve liderlerin çatışma yönetimi stratejilerini kullanma düzeylerinin çalışanlar tarafindan algılanması konulu yüksek lisans çalışmasında elde ettiği bulgulara göre; çalşsanlar yöneticilerini dönüşümcü lider olarak algillyorlarsa, çalısanlara göre bu liderlerin daha çok bütünleştirme, uyma ve uzlaşma stratejilerini kullandıklarını belirtmiştir. Eğer çalısmaya katılanlar yöneticilerini etkileşimci lider olarak algillyorlarsa, çalısanlara göre yöneticilerinin çatısmaların çözümünde büyük oranda hükmetmeyi ya da daha düşük oranda kaçınma stratejisini kullandıkları görülmüştür.

$\mathrm{Bu}$ çerçevede çalışmada yer alan çalışanlar, yöneticilerini etkileşimci lider olarak görmektedirler denilebilmektedir.

\section{Sonuç}

Hastaneler ürettikleri hizmetler nedeni ile karmaşık yapıda ve dinamik sisteme sahip, dikey ve yatay iletişimin, görev ve sorumlulukların çok olduğu, ertelenemez ve kesintisiz hizmet vermek zorunda olan işletmelerdir. Bu nedenle yöneticilerin çalışanlarla ilgili oluşacak bireysel ve örgütsel çatışmaları uygun çatışma çözme yöntemleri ile çözmesi önem arz etmektedir.

Yeni yönetim anlayışında çatışmaların işletmeler için yararlı olduğu ve işletmelerin gelişmesine önemli katk1 sağladığı kabul görmektedir. Çatışmaların yönetiminde taraflar çatışma yönetim stratejilerinden bir veya birkaçını kullanabilmektedirler. Literatürde en çok üzerinde durulan beş çatışma yönetim stratejisi; Problem çözme, uyma, uzlaşma, kaçınma ve hükmetme yöntemidir. Bu stratejilerden bütünleştirme (problem çözme) yaklaşımının çatışmaların çözümünde uygun yöntem olduğu ifade edilmekle birlikte, yönetim yaklaşımlarından durumsallık yaklaşımı, tek bir yöntemin her zaman en geçerli yöntem olmadığı, duruma ve şartlara göre diğer yöntemlerin de çatışma çözmek için kullanılabileceğini ortaya koymaktadır.

Çalışmamızda, araştırmaya katılan gruptaki çalışanlara göre, yöneticilerin yetki ve otoritelerini kullanarak çatışmaları çözmeye çalsştıkları, yöneticilerin en çok kullandıkları bu stratejik araç olarak da hükmetme yöntemi olduğunu belirtilmiştir. Çalışmadan çıkan sonuçlar aşağıda maddeler halinde belirtilmiştir;

- Çalısanlar yöneticilerinin kullandıkları çatışma çözme stratejilerinden en yüksek düzeyde hükmetme, en düşük düzeyde uyma çatşma çözme stratejisinin uygulandığını belirtmişlerdir. Kadın çalısanlar erkek çalısanlara göre, yöneticilerin hükmetme stratejisini daha çok kullandıklarını belirtmişlerdir.

- Araştırmada bazı meslek gruplarında (sekreter ve hemşire) çatışma çözme stratejisi olarak, hükmetme stratejisinin yöneticiler tarafından daha çok kullanıldığının belirtildiği görülmüsstür. Bu iki meslek grubunda çalışanların, çoğunlukla kadın olması sebebiyle; kadınlar çatışmalardan daha fazla etkilenmektedir denilebilir.

- Unvanlara göre yapılan analizde doktor unvanına sahip çalışanlar, yöneticilerinin bütünleştirme ve uyma stratejisini daha çok kullandıklarını belirtmişlerdir.

- Çalışanların verdikleri yanıtlara incelendiğinde yöneticilerinin eğitim durumuna göre; eğitim durumu lisans olan yöneticiler hükmetme stratejisini kullanırken, eğitim durumu tıpta uzmanlık/doktora olan yöneticilerin ise bütünleştirme, uyma, uzlaşma ve kaçınma stratejilerini, diğer eğitim gruplarından daha çok kullandıkları görülmüştür.

Bu nedenle;

- Hastanelerde problem çözme yaklaşımının kişisel ve gruplar arası çatışmaların çözümünde daha etkin kullanilması gerekmektedir.

- Bazı meslek gruplarında (sekreter ve hemşire) yöneticilerine karşs algılanan hükmetme çatısma çözme stratejisinin nedenlerinin belirlenmesi ve çözüm yöntemlerinin geliştirilmesi önem arz etmektedir. 


\section{Etik Beyan}

"Hastane Calssanlarna Göre Yöneticilerin Catısma Çözme Stratejileri” başlıklı çalışmanın yazım sürecinde bilimsel, etik ve alıntı kurallarına uyulmuş; toplanan veriler üzerinde herhangi bir tahrifat yapılmamıs ve bu çalışma herhangi başka bir akademik yayın ortamına değerlendirme için gönderilmemiştir.

\section{Kaynakça}

Akca, C. ve Erigüç, G. (2007). Hastane çalışanlarının yöneticileri ve çalışma arkadaşları ile yaşadıkları çatışma nedenlerine yönelik bir araştırma. Hacettepe Sağhlk İdaresi Dergisi, 9(2), 126-153.

Aslan, Ş. (2004). Hastanelerde örgütsel çatışma: teori ve örnek bir uygulama. Selçuk Üniversitesi Sosyal Bilimler Dergisi, 11, 599-617.

Baltac1, T. (2013) Yeni liderlik yaklașımlarmn ve liderlerin çatssma yönetimi stratejilerini kullanma düreylerinin çalışanlar tarafindan algzlanmasi: Kastamonu hastaneleri ömeği (Yüksek Lisans Tezi). Ufuk Üniversitesi Sosyal Bilimler Enstitüsü, Ankara.

Kıdak, L. B., Demir, S., Çeber, E. ve Turgay, A. S. (2011). İzmir'de bir hastanede yöneticilerin çatışma yönetim stilleri ve çalışanların algılamaları. Hacettepe Sağhlk İdaresi Dergisi, 14(1), 1-25.

Kılınç, E., Hasdemir, S. ve Ulusoy, H. (2018). Sağlık kurumlarında çatışma ve çatışma yönetimi. Sağlık. Yönetimi ve Liderlik Dergisi, 1, 34-47.

Koç, N. (2017). Sağhlk çalışanlarnnda çatısma yönetimi (Yüksek Lisans Tezi). Beykent Üniversitesi Sosyal Bilimler Enstitüsü, İstanbul.

Kösehan, A. (2005). Örgütlerde çatısma ve yönetimi, Deniəlli'de bir örnek (Yüksek Lisans Tezi). Pamukkale Üniversitesi Sosyal Bilimler Enstitüsü, Denizli.

Oktay, F. (2016). Çatışma yönetimi ile örgütsel destek arasındaki ilişkinin incelenmesi. Gą̧iantep Üniversitesi Sosyal Bilimler Dergisi, 15(4), 1146-1155.

Önder, G., Aybas, M. ve Önder, E. (2014). Hemşirelerin stres seviyesine etki eden faktörlerin öncelik sırasının çok kriterli karar verme tekniği ile belirlenmesi. Optimum Ekonomi ve Yönetim Bilimleri Dengisi, 1(1), 21-35.

Rahim, M. A. (2002). Toward a theory of managing organizational. International Journal of Conflict Management, 13(3), 206-235.

Şahin, A., Emini, F. T. ve Ünsal, Ö. (2006). Çatışma yönetimi yöntemleri ve hastane örgütlerinde bir uygulama. Selcuk. Üniversitesi Sosyal Bilimler Dergisi, 15, 553-568.

Tozkoparan, G. (2013). Beş faktör kişilik özelliklerinin çatışma yönetim tarzlarına etkisi: Yöneticiler üzerinde bir araştırma. Ekonomik ve Sosyal Araşttrmalar Dergisi, 9(2), 189-231.

Uslu, S. (2015) Çatısma yönetimi ve işten ayrlma niyeti arasindaki ilişki: sağhlk çalışanlar üzerine bir araștrma (Yüksek Lisans Tezi). Sakarya Üniversitesi Sosyal Bilimler Enstitüsü, Sakarya.

\section{EXTENDED ABSTRACT}

This study aims to determine the opinions of the health staff working in Elazig City Hospital about the conflict resolution strategies used by their managers. Survey method was used as the data collection tool. This research used the conflict management strategies scale named ROCI II consisting of 28 items developed by Rahim, M. Afzalur. The reliability of the measurement tool was 0.87 . The survey was applied to 158 people in the hospital and 134 questionnaires were included in the evaluation. Since the data fit the normal distribution, t-test and one-way analysis of variance were performed.

This study investigated the relationship between the demographic characteristics of the hospital staff and their perception of conflict resolution strategies of their managers. There is a significant $(p<0.05)$ relationship between gender and title of hospital staff and their perceptions regarding the managers' conflict resolution strategies sub-dimensions. Accordingly, the perception of the female employees about conflict management of their managers $(\overline{\mathrm{x}}=3.11)$ is higher than that of male personnel $(\overline{\mathrm{x}}=2.95)$. According to the hospital staff, female managers use the strategy of integration $(\overline{\mathrm{x}}=3.11)$, and male managers use the strategy of domination ( $\overline{\mathrm{x}}$ $=3.19)$. There is a significant difference between secretaries, nurses, and other professional groups. The perception of hospital staff about their managers' conflict resolution strategies is at a medium level with $\overline{\mathrm{x}}=$ 3.03. According to the hospital staff, the conflict resolution strategies used by their managers are as follows, respectively: domination $(\bar{x}=3.18)$, avoidance $(\bar{x}=3.09)$, integration $(\bar{x}=3.03)$, compromise $(\bar{x}=2.98)$ and compliance $(\bar{x}=2.90)$. As the age and service year of the participants increase, the perceptions about the conflict resolution strategy of their managers increase, too.

Hospitals are organizations with a service-intensive organizational structure. These services are urgent and non-delay able. Therefore, individual and other conflicts that will affect the operation of the system should be resolved without a moment to spare. Participant staff in the study stated that the managers they are affiliated 
with use dominating strategy at the highest degree and compliance strategy at the lowest degree. The reason for this is that the hospitals are in the matrix organization structure and different divisions of work and specializations are involved. The services should be sequential and many units of the services should be interrelated, and this structure of the hospital service process should continue without any interruption. Managers should resolve conflicts that will occur within this process without delay. It is thought that management authority is used primarily for the resolution of conflicts by the managers. Problem-solving approach should be used more effectively in the resolution of conflicts in hospitals.

According to female employees, managers use the strategy of domination at most among the conflict resolution strategies sub-dimensions, while male employees state that managers use the compliance strategy at the highest degree. Besides, female employees stated that managers also use the strategies of integrating, avoiding, and reconciling strategies with a higher average than male employees. However, this difference was only significant in the dimension of domination. Kidak et al. (2011 found a statistically significant difference between the perceptions and the gender of the employees and their perceptions about the conflict management styles used by the managers. In their study, the female participants had higher perceptions than male employees about the strategies of integration, avoidance, and reconciliation are perceived to be used by managers. Similar results were obtained in our study; however, this difference was significant in the dominant dimension.

There is a significant difference between the secretary and nurse and other titles concerning the perception of the dominant strategy used by the managers. The majority of the employees with the title of secretary and nurse are female employees, and they stated that the managers use the domination strategy more. Employees with the title of doctor stated that their managers use the integration and compliance strategy more. This difference is thought to be related to the work. The work carried out in hospitals cannot be postponed due to the characteristics of the services and they must be carried out in a system approach in connection with each other. Otherwise, a malfunction in one place affects the entire system.

The new management approach assumes that conflicts are beneficial for businesses and contribute significantly to the development of businesses. Parties can use one or more conflict management strategies in the management of conflicts. The five most emphasized conflict management strategies in the literature are problemsolving, compliance, reconciliation, avoidance, and domination. Although, it is stated that the integration (problem-solving) approach from these strategies is the appropriate method for resolving conflicts, the contingency approach, which is one of the management approaches, reveals that a single method is not always the most valid method, and other methods can be used to resolve conflicts according to the situation and conditions.

The participant employees stated that the most used strategy of the managers is to try to resolve conflicts by using their powers and authorities of the managers, and the method of domination is used as this strategic tool. The results of the study are stated below as items:

- Employees stated that the domination and conflict resolution strategies are used by their managers at the highest and lowest degree, respectively. Female employees stated that managers use the dominance strategy more than male employees.

- In some occupational groups (secretaries and nurses), the strategy of domination is stated to be used more by the managers as the conflict resolution strategy. Since the employees of these two professions are mostly women; it can be said that women are more affected by conflicts.

- In the analysis by titles, doctors stated that their managers use the integration and compliance strategy more.

- According to the training level of their managers, the undergraduate managers use the dominance strategy, whereas the managers with a specialization in medicine/doctorate degrees use the integration, compliance, reconciliation, and avoidance strategies more than other education groups.

Therefore;

- The problem-solving approach should be used more effectively in the resolution of personal and intergroup conflicts in hospitals.

In some occupational groups (secretaries and nurses), it is important to identify the causes of perceiving domination as the conflict resolution strategy and develop solution methods. 